\title{
PENYULUHAN PENGELOLAAN LIMBAH TAMBAK UDANG RAMAH LINGKUNGAN DI DESA TAMBAKSARI-KARAWANG
}

\author{
Laila Febrina', Ira Mulyawati ${ }^{2}$, Ibnu Fazhar ${ }^{3}$ \\ Prodi Teknik Lingkungan, Fakultas Teknik, Universitas Sahid \\ Jl. Prof. Dr. Soepomo No. 84 Jakarta \\ Email Korespondensi: lailahardian@gmail.com
}

\begin{abstract}
ABSTRAK
Desa Tambak Sari adalah salah satu desa Kabupaten Karawang, Jawa Barat. Salah satu potensi di desa itu tersebut adalah budidaya tambak udang. Sisa Pakan udang berpotensi menjadi limbah yang mencemari lingkungan. Meningkatnya jumlah usaha budidaya udang akan berimbas pada tingginya beban limbah produksi pada perairan sekitar. Oleh karena itu para petani tambak perlu memiliki pengetahuan pengelolaan limbah budidaya tambak udang yang ramah lingkungan guna menjamin keberlanjutan usaha petani tambak. Kegiatan yang dilakukan dalam PKM ini adalah penyuluhan kepada para petani tambak mengenai metode yang dapat diterapkan dalam meminimalisasi limbah tambak udang. Alternatif yang dapat dilakukan adalah dengan aerasi dan penanaman tanaman air dengan metode construted wetland. Target luaran yang dicapai pada kegiatan ini adalah peningkatan partisipasi dan pengetahuan petani tambak sehingga menjadikan Desa Tambak Sari menjadi desa yang ramah lingkungan dalam pengelolaan limbah tambak udangnya.
\end{abstract}

Kata kunci : pakan udang, limbah, Construted Wetland

\begin{abstract}
Tambak Sari Village is one of the Karawang Regency villages, West Java. One of the potentials in the village is shrimp farming. Remaining shrimp feed has the potential to become waste that pollutes the environment. The increasing number of shrimp farming businesses will impact on the high burden of production waste in the surrounding waters. Therefore pond farmers need to have knowledge of the management of shrimp ponds environmentally friendly waste management in order to ensure the sustainability of pond farmer businesses. The activity carried out in this PKM is counseling to farm farmers about methods that can be applied in minimizing shrimp pond waste. The alternative that can be done is by aeration and planting of aquatic plants using the construted wetland method. The output target achieved in this activity is to increase the participation and knowledge of pond farmers so that the Village of Tambak Sari becomes an environmentally friendly village in the management of shrimp pond waste
\end{abstract}

Keywords: Ecossava, Composting, Takakura, Verticulture, Cassava 


\section{PENDAHULUAN}

Desa Tambak Sari di Karawang merupakan desa yang dikenal sebagai sentra budidaya udang. Dinilai dari jumlah yang diekspor, memang terkesan menggiurkan. Namun, beragam persoalan lingkungan juga mengemuka. Di antaranya soal pembuangan limbah tambak udang. Berkembangnya tambak udang di desa tambak sari menimbulkan persoalan baru dalam lingkungan. Persoalan yang muncul adalah akumulasi limbah yang mengakibatkan pencemaran, masih banyak pemilik tambak udang yang tidak melakukan pengolahan limbahnya. Limbah udang berupa unsur organik, biasanya sisa pakan, yang dapat mengganggu keseimbangan ekosistem pantai. Unsur organic yang terakumulasi dapat meningkatkan populasi alga yang mengganggu komunitas ikan. Limbah udang juga dapat mengganggu budidaya ikan yang lain yang terdapat di pantai. Berdasarkan hal tersebut perlu adanya pengelolaan limbah udang agar dapat akumulatif dari limbah tersebut dapat diminimalisir. "Untuk limbah tambak skala kecil, pengelolaan limbah bisa dengan saluran sehingga bisa untuk retention. Ini akan memacu sedimentasi unsur-unsur yang tersisa hingga tak terbuang langsung." Selain itu, pengelolaan juga bisa dilakukan dengan melibatkan ikan ataupun rumput laut. Adanya rumput laut dan ikan akan membantu mengurangi akumulasi limbah organik tambak udang. Pengolahan limbah ini adalah salah satu bentuk budidaya yang bertanggung jawab.

Desa Tambaksari merupakan salah satu dari 11 Desa di Wilayah Kecamatan Tirtajaya Kabupaten Karawang Propinsi Jawa Barat. Desa tersebut terletak di sebelah paling utara dari Kecamatan Tirtajaya dan berbatasan dengan desa Tambaksumur, Desa Medan karya Kecamatan Tirtajya, dan Desa Karya bakti Kecamatan Batujaya. Letak geografis Kecamatan Tirtajaya berada pada jarak $8 \mathrm{Km}$ dari pantai utara pulau jawa dengan ketinggian 3 meter dari permukaan laut. Suhu udara rata-rata $27^{\circ} \mathrm{C}$ dengan curah hujan tahunan berkisar antara 1-100-3.200 mm/th. Luas kecamatan Tirtajaya adalah sekitar 11.362.815 Ha, meliputi daratan, pesawahan dan area tambak dengan jumlah penduduk 70.002 terdiri atas 34.940 laki-laki dan 35.062 perempuan. Selanjutnya terlihat pada gambar 1. dibawah ini lokasi kecamatan Tirtajaya berdasarkan peta batas wilayah Kabupaten Karawang. Para penambak udang lebih didominasi oleh para pria atau kepala rumah tangga di Desa Tambaksari. Jumlah Kartu Keluarga hanya sekitar 200 sampai 600 jiwa. Dengan zona yang kecil tentu sangat mudah untuk mensejahterakan suatu daerah. Tetapi jika permasalahan lingkungan tidak diperhatikan terkait limbah tambak udang, maka dikhawatirkan keberlanjutan tambak udang menjadi terganggu. Produksi budi daya udang di wilayah pertambakan desa tambaksari sangat bergatung pada kualitas dan kadar air yang masuk ke lahan tambak melalui sungai seruni (Karawang news,2015)

Berdasarkan hal tersebut, Universitas Sahid bekerjasama dengan Pemerintah Desa

Tambak Sari Kabupaten Karawang melaksanakan Program Pengabdian Kepada Masyarakat (PKM). Melalui program penyuluhan pengelolaan limbah tambak udang yang ramah lingkungan sehingga diharapkan akan berdampak kepada keberlanjutan dari usaha tambak udang yang secara tidak langsung mendukung program pemerintah daerah dalam meningkatkan kesejahteraan dan mengurangi jumlah masyarakat miskin. Secara umum, tujuan dan sasaran kegiatan ini adalah peningkatan partisipasi petani tambak Desa Tambak Sari, Kabupaten Karawang melalui program penyuuhan mengenai pengelolaan limbah tambak udang yang ramah lingkungan dengan metode construted wetland. 


\section{METODE PELAKSANAAN}

Prosedur pelaksanaan kegiatan PKM di Desa Tambak Sari Kabupaten Karawang yakni: (1) Melaksanakan koordinasi dengan perangkat desa mengenai permasalahan yang terdapat di Desa Tambak Sari (2) Melaksanakan kegiatan penyuluhan dalam rangka sosialisasi pemahaman serta memotivasi petani tambak dalam pengelolaan limbah tambak udang yang ramah lingkungan dengan memanfaatkan media alami dengan metode constructed wetland dan penambahan kincir angin untuk penambahan aerasi pada tambak udang dan ikan.

\section{HASIL DAN PEMBAHASAN}

Pada tahap persiapan ini Tim PKM telah berkoordinasi pihak mitra dalam hal ini sekretaris Desa (bapak Sumanta) melalui diskusi secara media online, dan juga melalui petani tambak udang yaitu Bapak Ate. Dari hasil diskusi ini diperoleh kesepakatan waktu untuk melaksanakan kegiatan PKM yaitu sosialisasi kegiatan kepada masyarakat, transfer pengetahuan mengenai pengelolaan limbah cair tambak udang dan aplikasinya di lapangan

Pada saat koordinasi dengan pihak desa mitra, mereka menyambut baik dan berharap masyarakat desa khusunya petani tambak mendapat manfaat dari kegiatan ini. Mereka antusias dengan program penyuluhan pengelolaan limbah tambak udang, karena sebagian wilayah tambak udang tidak memiliki pengelolaan limbahnya, sebagian besar langsung dibuang ke lingkungan.
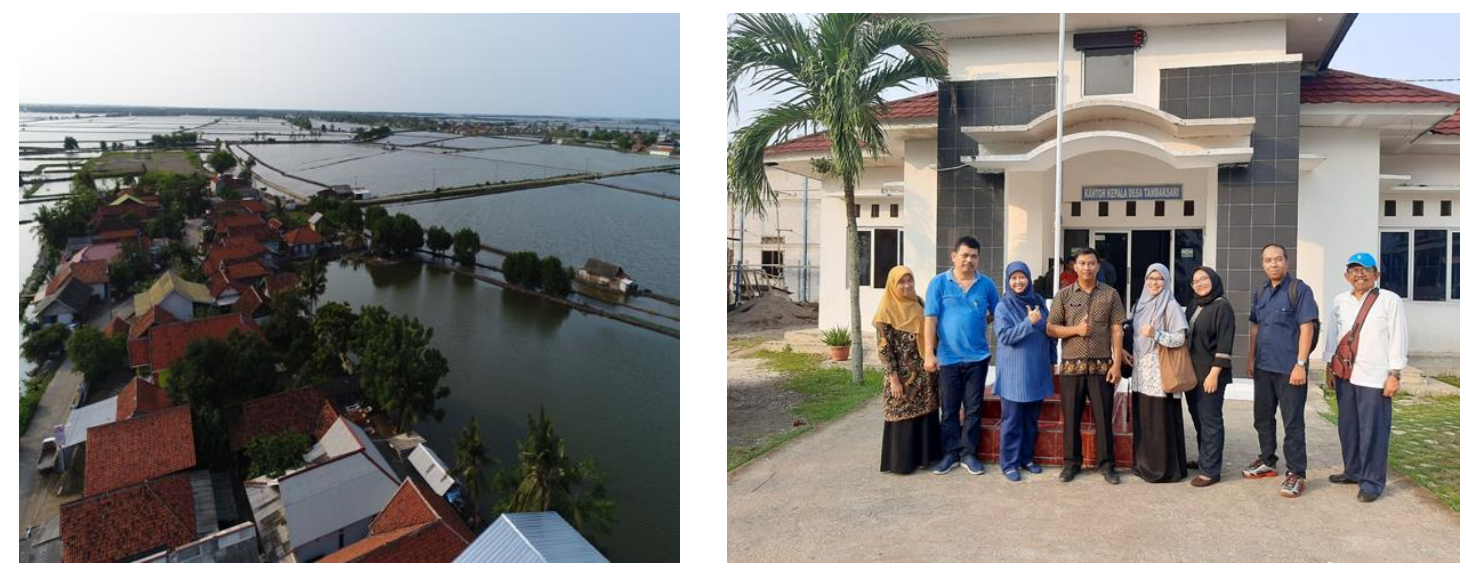

Gambar 1. Desa Tambak Sari Kabupaten Karawang

Pada Kegiatan pelaksanaan dari kegiatan PKM ini adalah melaksanakan sosialisasi kepada masyarakat desa mengenai sumber limbah pada pakan ternak serta tambak udang serta dampaknya pada lingkungan perairan. Selanjutanya dipaparkan berbagai teknik pengelolaan limbah tambak udang melalui media alami dengan menggunakan metode construted wetland. 

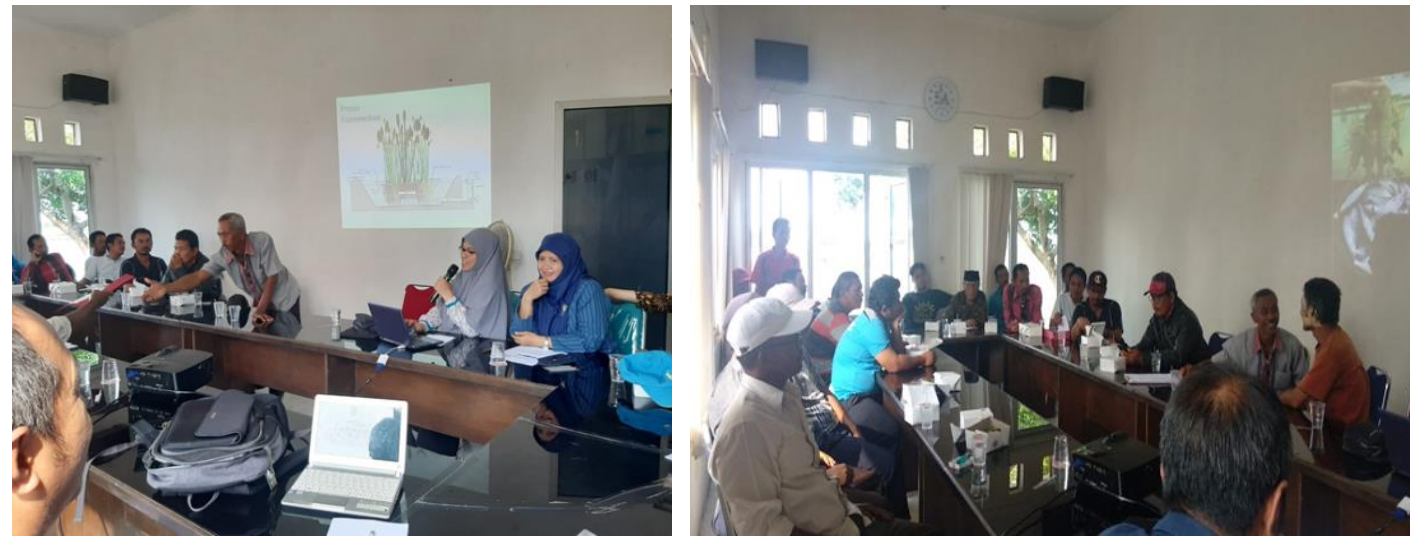

Gambar 2. Sosialisasi dan penyuluhan pengelolaan Limbah Tambak Udang

Pada penyuluhan ini dipaparkan bahwa limbah tambak udang merupakan cairan buangan yang berasal dari kolam yang bangun untuk budidaya udang.Sumber Limbah : Dari sisa pakan udang yang tidak termanfaatkan (limbah organik hasil metabolisme dan sisa pakan. Limbah tambak udang terdiri atas; 35\% limbah organik, sisa pakan $15 \%$ dan sisa metabolisme udang 20\%. Limbah yang semakin meningkat akan mengalami proses dekomposisi (penguraian) yang akan menghasilkan nitrit dan ammonia, karena tidak semua pakan dikonsumsi udang. Sisa pakan dan feses udang dapat tertinggal di dasar tambak, hal ini yang dapat memicu penurunan kualitas air yang dapat menghambat pertumbuhan udang

Karakteristik limbah tambak udang terdiri atas karakter kimia dan karakter fisika,

\section{Karakteristik Fisika}

a) total padatan (total solid), suhu, warna dan bau.

b) Suhu 40-46 C

c) Total padatan meliputi padatan terlarut, terendam, terapung, tersuspensi dan koloid.

d) Limbah cair tambak udang berwarna kuning keruh dan berbau busuk

\section{Karakteristik Kimia}

a) Limbah tambak udang mengandung bahan organik yang terdiri dari protein, karbohidrat dan bahan anorganik lain seperti nitrogen, fosfor dan ammonia. Protein berasal dari sisa pakan udang.

b) limbah tambak udang bersifat basa dengan kisaran $\mathrm{pH}$ 7-9.

Limbah tambak udang yang terdapat di Desa Tambak Sari sebagian besar dalam pertanian yang alami dan sebagian lagi bersifat ekstensif. Pada tambak intensif, pertani tambak udang telah membagi tambak dalam empat sekat dengan tiap sekat memiliki funsgi yang berbeda-beda . sementara itu pada petani dengan tambak alami, hanya tersdiri dari satu tambak besar saja, tanpa sekat. Tidak terlihat adanya aerasi yang menjadi sumber oksigen bagi udang. Untuk mengatasi permasalahan aerasi, maka para petani tambak tadi mencampurnya dengan ternaik ikan bandeng. Dimana ikan bandeng tersebut digunakan oleh mereka sebagai kincir ( kegiatan ikan yang berenang-renang menghasilkan suplly oksigen). Tetapi hal ini dirasa kurang masksimal, karena para petani banyak yang mengeluhkan ternak udang dan bandengnya banyak yang mati dikarenakan penyakit. 
Sementara itu, limbah tambak udang ketika telah selesai panen dialiran ke saluran dan dibuang ke perairan lepas, hal jika dibiarkan terus menerus tanpa pengolahan dapat mencemari lingkungan. Berdasarkan apa yang telah dipaparkan oleh para petani pada saat diskusi maka ada beberapa hal yang perlu menjadi perhatian para petani tambak udang. Pengelola tambak perlu mengelola limbahnya agar dapat menjadi kelestarian lingkungan perairan. Untuk limbah tambak skala kecil, pengelolaan limbah dapat memanfaatkan saluran untuk retention. Ini akan memacu sedimentasi unsur-unsur yang tersisa hingga tak terbuang langsung. Alternatif pengelolaan limbah tambak udang dapat menggunankan tanaman airnya sebagai media menurunkan parameter limbah. Alternatif tersebut antara lain :

1. Metode Construted Wetland dengan tanaman air seperti eceng gondok

2. Penambahan Ikan dan rumput laut

3. Menggunakan tanam rumput vertiver.
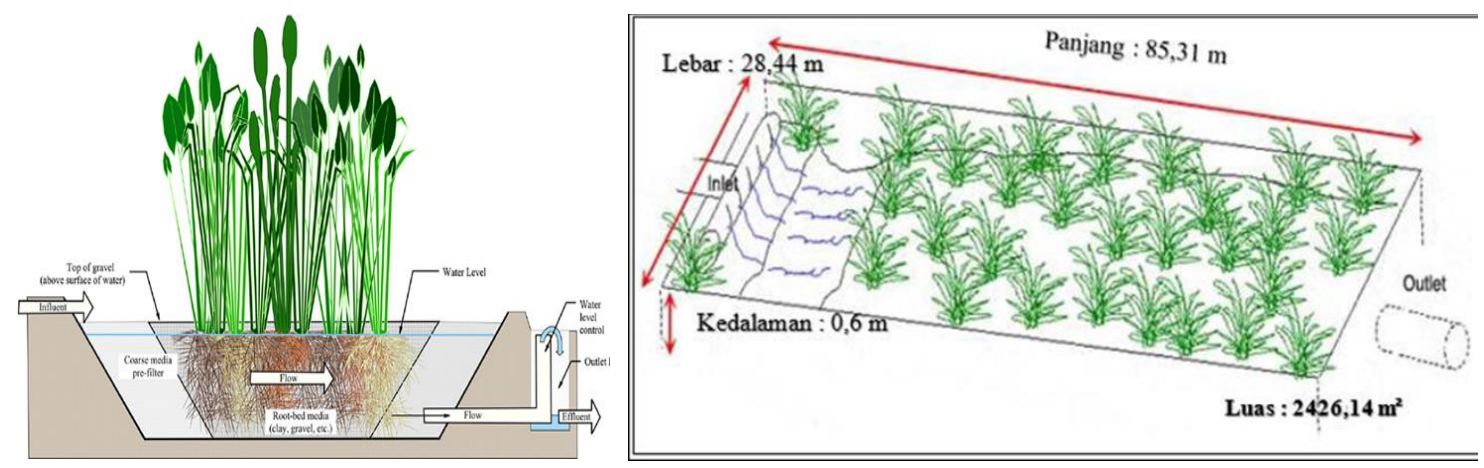

Sumber : Sarah A.White, 2013

Gambar 4.5. Ilustrasi Construted Wetland

Pengaliran air limbah tambak udang ke kolam wetland akan mendukung penurunan parameter pencemar pada limbah tambak udang. Penambahan kolam aerasi sebelum air limbah memasuki wetland juga yang akan mendukung dalam proses penurunan konsentrasi parameter amonia terlarut yang umumnya da pada limbah cair tambak udang. Wetland berisi tumbuhan eceng gondok tersebut dibuat secara sederhana dengan ukuran yang dapat menyesuaikan lahan yang ada, dibuat seperti membuat kolam pada umumnya namun bagian bawahnya tidak dilapis baik dengan beton maupun plastik namun langsung bersentuhan dengan tanah. Alasan mengapa tanaman eceng gondok dapat dipilih pada wetland ini atau fitoremediasi adalah :

a) eceng gondok memiliki daya adaptasi yang besar terhadap berbagai macam hal yang ada di sekelilingnya dan dapat berkembang biak dengan cepat.

b) Eceng gondok dapat hidup di tanah yang selalu tertutup oleh air yang banyak mengandung makanan

c) Selain itu tumbuhan eceng gondok juga merupakan tumbuhan yang sangat mudah didapat disamping tumbuhan tersebut merupakan tumbuhan pengganggu

Selain itu, pengelolaan juga bisa dilakukan dengan melibatkan ikan ataupun rumput laut. Adanya rumput laut dan ikan akan membantu mengurangi akumulasi limbah 
organik tambak udang. Alternatif yang lain yang dapat digunakan untuk menurunkan parameter pada limbah tambak udang adalah dengan menggunakan tanaman rumput vetiver (Chrysopogon zizanioides, $L$ ). Rumput vetiver mempunyai kemampuan hidup dalam cakupan kondisi yang sangat beragam dan luas, baik terhadap kondisi iklim, habitat, dan kualitas air serta perairan bersalinitas. Vetiver juga memiliki persen penghilangan tinggi untuk $\mathrm{N}$ dan $\mathrm{P}$ dari limbah cair (Truong dan Hart, 2001; Truong dan Loch, 2004; Truong dkk., 2008; Vimala dan Kataria, 2004;

\section{KESIMPULAN}

Kesimpulan yang diperoleh dari kegiatan ini adalah: (1) Partisipasi masyarakat dalam mengikuti kegiatan penyuluhan dan pendampingan ini cukup aktif. Dilihat dari tingkat partisipasi yang tetap mengikuti setiap sessi pelatihan hingga selesai dan hadir tepat waktu.(2) Sebagian besar mitra dan peserta pelatihan memiliki penambahan pengetahuan mengenai pengelahan limbah tambak udang; (3) Peserta pelatihan dapat berdiskusi dengan tim PKM terkait kendala mereka didalam meningkatkan produksi tambak mereka (ada nya wadah penyampaian harapan mereka terkait keberlanjutan tambak.

\section{DAFTAR PUSTAKA}

Bratasida, L. (1996). Prospek Pengembangan Sistem Manajemen Lingkungan di Indonesia. BAPEDAL. Jakarta..

Fitriyah, N. (2000). Usaha Budidaya Tambak Udang Windu dan Bandeng di Desa Ambeng-ambeng, Kecamatan Duduk Sampeyan Kabupaten Gresik, Skripsi Surabaya: Universitas Negeri Surabaya.

Masyhud, A. (2006). Manajemen Resiko Strategi Perbankan dan Dunia Usaha Menghadapi Tantangan Globalisasi Bisnis. Jakarta: Raja Grafindo Persada.

Raharjo, S., Suprihatin, S., Indrasti, N. S., Riani, E., Supriyadi, S., \& Hardanu, W. (2015). Lahan Basah Buatan Sebagai Media Pengolahan Air Limbah Budidaya Udang Vaname (Litopenaeus Vannamaei) Bersalinitas Rendah (Constructed Wetland for Remediation of Brackish Wastewater From White Shrimp (Litopenaeus Vannamaei) Cultivation). Jurnal Manusia dan Lingkungan, 22(2), 201-210.

Suhartini, S., \& Farikhah, F. (2016). IbM Petani Udang Windu Duduksampeyan Gresik Jawa Timur.

Suwoyo, H. S., Fahrur, M., Makmur, M., \& Syah, R. (2017). Pemanfaatan Limbah Tambak Udang Super-Intensif Sebagai Pupuk Organik Untuk Pertumbuhan Biomassa Kelekap Dan Nener Bandeng. Media Akuakultur, 11(2), 97-110.

Soeratmo, F. G. (1988). Analisis mengenai dampak lingkungan. Gadjah Mada University Press.

White, S. A. (2013). Wetland technologies for nursery and greenhouse compliance with nutrient regulations. HortScience, 48(9), 1103-1108. 